\title{
Response of Pre-Harvest Spraying Treatments of Chemicals and Plant Growth Regulators on Post-Harvest Losses and Quality Attributes of Sapota [Manilkara achras (Mill.) Forsberg] Fruits cv. Kalipatti
}

\author{
V.N. Desai*, B.N. Satodiya and A.B. Desai \\ Department of Horticulture, B. A. College of Agriculture, Anand Agricultural University, \\ Anand 388110, Gujarat, India \\ *Corresponding author
}

\section{A B S T R A C T}

\begin{abstract}
Keywords
Sapota, Pre-harvest,

Calcium chloride,

Calcium nitrate,

Calcium sulphate

and Potassium

chloride, GA3,

NAA.

Article Info

Accepted:

10 July 2017

Available Online:

10 September 2017

Investigation was conducted to study the "Response of pre-harvest spraying treatments of chemicals and plant growth regulators on post-harvest losses and quality attributes of sapota fruit cv. Kalipatti”. 15 years old sapota trees were sprayed one month before harvest with different chemicals (Calcium chloride @ 2\%, Calcium nitrate@2\%, Calcium sulphate@2\% and Potassium chloride @ 2\%) and different level of plant growth regulators $\left(\mathrm{GA}_{3} @ 50\right.$ and $100 \mathrm{mg} /$ 1, NAA@ 50 and $100 \mathrm{mg} / \mathrm{l}$ ) along with control (Water spray and Absolute). Harvested fruitswere stored in laboratory at room temperature. Pre harvest spray of $\mathrm{CaCl}_{2} @ 2 \%$ recorded minimum physiological loss in weight, spoilage percentage with maximum TSS, total sugar, reducing sugar, nonreducing sugar and ascorbic acid during 12 days storage period of the sapota fruit.
\end{abstract}

\section{Introduction}

Sapota (chiku) is native to tropical America, belongs to family Sapotaceae. Sapota rank fifth both in production and consumption next to mango, banana, citrus and grapes. South Gujarat is a horticulture belt where Kalipatti variety is grown on large area. Sapotais highly perishable and rated very poor for process ability and it is mainly used for table purpose. Being a climacteric nature during ripening fruit passes through a series of change in colour, texture and flavor indication that composition change are taking place. Sapota fruit ripens within 3 to 4 days after harvest and soon after full ripened stage, raped bio-chemical changes reduced the shelf life. To increase the shelf life through preharvest treatments is considered one of the major attempts in Sapota cultivation. Various chemicals have been used to hasten or delay ripening, to reduce losses and to improve and maintain colour and quality by slowing down the metabolic activities of fruit. These chemicals arrest the growth and spread of microorganism by reducing the shriveling which ultimately leads to an increased shelf life and maintain the marketability of the fruit 
for a longer period. Therefore the present investigation was carried out to assess the response of pre-harvest spraying treatments of chemicals and plant growth regulators on post-harvest losses and quality attributes of sapota [Manilkara achras (Mill.) Forsberg] fruit cv. Kalipatti.

\section{Materials and Methods}

The present investigation was carried out during the year 2015 at Horticulture Research Farm and P.G. Laboratory, Department of Horticulture, Anand Agricultural University, Anand. Thirty uniform trees of sapota cv. Kalipatti were marked and one month before harvest sprayed with different chemicals (Calcium chloride@2\%, Calcium nitrate@ $2 \%$, Calcium sulphate @ $2 \%$ and Potassium chloride@2\%) and different level of plant growth regulators $\left(\mathrm{GA}_{3} @ 50\right.$ and $100 \mathrm{mg} / 1$, NAA @ 50 and $100 \mathrm{mg} /$ 1) along with control (Water spray and Absolute). There were three replication comprising three plants per treatment. Fruits were harvested at optimum maturity stage from the representative tree.

Two $\mathrm{kg}$ fruits from each replication of each treatment were stored at room temperature in laboratory. The fruits were assessed at $6^{\text {th }}$, $9^{\text {th }}$ and $12^{\text {th }}$ day of storage for physiological loss in weight, spoilage percentage, TSS, acidity, total sugar, reducing sugar, nonreducing sugar and ascorbic acid.

The physiological loss in weight of stored fruits was calculated by subtracting final weight from the initial weight of the fruits and expressed in percent.

Spoilage percentage of fruit was calculated as the number of decayed fruit divided by intial number of all fruit multiplied by hundred. Total soluble solids of sapota fruit was recorded by using a Hand Refractometer (0- $32^{\circ}$ Brix). The titrametric method of Lane and Eynon described by Ranganna (1979) was adopted for the estimation of acidity, total sugar, reducing sugar and ascorbic acid. The experimental data was analyzed in completely randomized design with three repetitions.

\section{Results and Discussion}

Data presented in table 1 showed significantly minimum physiological loss in weight (4.61, 6.38 and $10.11 \%$ ) at $6^{\text {th }}, 9^{\text {th }}$ and $12^{\text {th }}$ day of storage period, respectively in treatment $\mathrm{T}_{1}$ $\left(\mathrm{CaCl}_{2} @ 2 \%\right)$ which was at par with treatment $\mathrm{T}_{2}\left[\mathrm{Ca}\left(\mathrm{NO}_{3}\right)_{2} @ 2 \%\right]$ i.e. 4.91, 6.97 and $10.28 \%$.

The reduction in weight loss might be due to the maintenance of firmness of fruits by calcium which decreased the enzyme activity responsible for disintegration of cellular structure and decreases the gaseous exchange.

The present investigation is in conformity with the results reported by Rajkumar et al., (2006) in papaya, Singh et al., (2013) in ber and Tsomu and Patel (2014) in sapota.The perusal of analysis showed (Table 1) significantly, the lowest spoilageloss (5.00, 38.33 and $65.00 \%)$ in treatment $\mathrm{T}_{1}\left(\mathrm{CaCl}_{2} @\right.$ $2 \%)$ at $6^{\text {th }}, 9^{\text {th }}$ and $12^{\text {th }}$ day of storage period, respectively followed by treatment $\mathrm{T}_{2}$ $\left(\mathrm{Ca}\left(\mathrm{NO}_{3}\right)_{2} @ 2 \%\right)$ i.e. 6.66, 41.67 and 68.33 $\%$.

Calcium treated fruits showed significantly lesser extent of rotting which might be due to the higher fruit flesh and calcium content in peel, which resulted stronger intracellular organization and rigidified cell wall.

The finding are agreement with the results reported of Lal et al., (2011) in apricot, Kirmani et al., (2013) in plum and Tsomu and Patel (2014) in sapota. 
At $9^{\text {th }}$ and $12^{\text {th }}$ day of storage period, the maximum TSS (22.22 and $20.37^{\circ}$ Brix, respectively) was observed in treatment $\mathrm{T}_{1}$ $\left(\mathrm{CaCl}_{2} @ 2 \%\right)$ which was at par with treatment $\mathrm{T}_{2}\left[\mathrm{Ca}\left(\mathrm{NO}_{3}\right)_{2} @ 2 \%\right]$ i.e 21.48 and $19.26^{0}$ Brixat $9^{\text {th }}$ and $12^{\text {th }}$ day of storage period. The increase in TSS during storage period might be due to hydrolysis of starch into sugar as on complete hydrolysis of starch no further increase occurs and subsequently decline in TSS is predictable.

Similar findings have been reported by Bhalerao et al., (2010) in sapota and Karemera and Habimana (2014) in mango.

Data presented in table 2 showed nonsignificant difference for acidity content among all the treatments during storage period. It was observed from the data (Table 2) that total sugar increase up to $9^{\text {th }}$ day of storage period and then after it started declining. The maximum total sugar (20.00, 22.61 and $18.34 \%$ ) was recorded with treatment $\mathrm{T}_{1}\left(\mathrm{CaCl}_{2} @ 2 \%\right)$ at $6^{\text {th }}, 9^{\text {th }}$ and $12^{\text {th }}$ day of storage period, respectively which, was at par with treatment $\mathrm{T}_{2}\left[\mathrm{Ca}\left(\mathrm{NO}_{3}\right)_{2} @ 2 \%\right]$ i.e 21.92 and $17.36 \%$ at $9^{\text {th }}$ and $12^{\text {th }}$ day of storage period, respectively.

The increase in total sugar during initial storage period might be due to hydrolysis of starch into sugar as on complete hydrolysis of starch no further increase occurs and subsequently a decline in total sugar is predictable.

The present investigation is in conformity with the results reported by Bhalerao et al., (2010) in sapota, Bisen et al., (2014) in guava and Karemera and Habimana (2014) in mango. The maximum reducing sugar (10.31, 11.98 and $9.98 \%$ ) was observed with treatment $\mathrm{T}_{1}\left(\mathrm{CaCl}_{2} @ 2 \%\right)$ at $6^{\text {th }}, 9^{\text {th }}$ and $12^{\text {th }}$ day of storage period, respectively which was at par with treatment $\mathrm{T}_{2}\left[\mathrm{Ca}\left(\mathrm{NO}_{3}\right)_{2} @ 2 \%\right]$ i.e. $10.10,11.80$ and $9.39 \%$.
The increase of reducing sugar content by calcium application might be due to the less utilization of sugar in respiration and conversion of starch in to sugar, while the subsequent decline was perhaps due to consumption of sugar for respiration during storage. The present investigation is in conformity with the results reported by Bhalerao et al., (2010) in sapota and Bisen et al., (2014) in guava.

The maximum non-reducing sugar (9.71, 10.63 and $8.36 \%$ ) was recorded in treatment $\mathrm{T}_{1}\left(\mathrm{CaCl}_{2} @ 2 \%\right)$ at $6^{\text {th }}, 9^{\text {th }}$ and $12^{\text {th }}$ day of storage period, respectively followed by treatment $\mathrm{T}_{2}\left[\mathrm{Ca}\left(\mathrm{NO}_{3}\right)_{2} @ 2 \%\right]$ i.e. 9.20, 10.12 and $7.97 \%$. The increase in nonreducing sugar during storage was due to the conversion of starch into sugar, while, the subsequent decrease in sugar was might be due to consumption of sugar for respiration during storage period. These results are in accordance with the findings of Bhalerao et al., (2010) in sapota, Bisen et al., (2014) in guava and Karemera and Habimana (2014) in mango.

Examination of data (Table 2) on ascorbic acid revealed that at $6^{\text {th }}, 9^{\text {th }}$ and $12^{\text {th }}$ day of storage period the highest ascorbic acid content $(21.23,16.16$ and $13.49 \mathrm{mg} / 100 \mathrm{~g}$ pulp, respectively) was recorded by treatment $\mathrm{T}_{1}\left(\mathrm{CaCl}_{2} @ 2 \%\right)$ followed by treatment $\mathrm{T}_{3}$ $\left(\mathrm{CuSO}_{4} @ 2 \%\right)$ i.e. 20.27 and $15.32 \mathrm{mg} / 100$ $\mathrm{g}$ pulp at $6^{\text {th }}$ and $9^{\text {th }}$ day of storage period, respectively.

The gradual reduction in ascorbic acid content during entire storage period might be due to its degradation through enzymatic oxidation of L-ascorbic acid to dehydro ascorbic acid during metabolic processes. Similar observations were recorded by Rajput et al.(2008) in guava, Ramezanian et al., (2009) in pomegranate and Bisen et al., (2014) in guava. 
Table.1 Influence of pre-harvest spraying treatments of chemicals and plant growth regulators on post-harvest losses

\begin{tabular}{|c|c|c|c|c|c|}
\hline $\begin{array}{l}\text { Sr. } \\
\text { No. }\end{array}$ & Parameters & Treatments & $\begin{array}{l}6^{\text {th }} \\
\text { Day }\end{array}$ & $\begin{array}{l}9^{\text {th }} \\
\text { Day }\end{array}$ & $\begin{array}{l}12^{\text {th }} \\
\text { Day }\end{array}$ \\
\hline \multirow{13}{*}{1.} & \multirow{13}{*}{$\begin{array}{c}\text { Physiological loss } \\
\text { in weight (\%) }\end{array}$} & $\mathrm{T}_{1}-\mathrm{CaCl}_{2} @ 2 \%$ & 4.61 & 6.38 & 10.11 \\
\hline & & $\mathrm{T}_{2--} \mathrm{Ca}\left(\mathrm{NO}_{3}\right)_{2} @ 2 \%$ & 4.91 & 6.97 & 10.28 \\
\hline & & $\mathrm{T}_{3}-\mathrm{CaSO}_{4} @ 2 \%$ & 9.12 & 12.34 & 17.57 \\
\hline & & $\mathrm{T}_{4}-\mathrm{KCl} @ 2 \%$ & 9.84 & 13.57 & 18.52 \\
\hline & & $\mathrm{T}_{5^{-}}-\mathrm{GA}_{3} @ 50 \mathrm{mg} / 1$ & 7.29 & 11.11 & 16.41 \\
\hline & & $\mathrm{T}_{6}-\mathrm{GA}_{3} @ 100 \mathrm{mg} / \mathrm{l}$ & 6.40 & 9.78 & 13.75 \\
\hline & & $\mathrm{T}_{7}-\mathrm{NAA} @ 50 \mathrm{mg} / 1$ & 8.50 & 11.34 & 15.77 \\
\hline & & $\mathrm{T}_{8}$ - NAA @ $100 \mathrm{mg} / \mathrm{l}$ & 7.90 & 10.91 & 15.17 \\
\hline & & $\mathrm{T}_{9^{-}}$Control (Water spray) & 10.56 & 14.97 & 19.99 \\
\hline & & $\mathrm{T}_{10^{-}}$Control (Absolute) & 13.11 & 17.11 & 23.35 \\
\hline & & S.Em. \pm & 0.40 & 0.52 & 0.62 \\
\hline & & C.D. $(\mathrm{P}=0.05)$ & 1.08 & 1.53 & 1.82 \\
\hline & & C.V. $\%$ & 7.71 & 7.84 & 6.65 \\
\hline \multirow{12}{*}{2.} & \multirow{12}{*}{ Spoilage loss (\%) } & $\mathrm{T}_{1^{-}} \mathrm{CaCl}_{2} @ 2 \%$ & 5.00 & 38.33 & 65.00 \\
\hline & & $\mathrm{T}_{2-} \mathrm{Ca}\left(\mathrm{NO}_{3}\right)_{2} @ 2 \%$ & 6.66 & 41.67 & 68.33 \\
\hline & & $\mathrm{T}_{3}-\mathrm{CaSO}_{4} @ 2 \%$ & 20.00 & 55.00 & 80.00 \\
\hline & & $\mathrm{T}_{4}-\mathrm{KCl} @ 2 \%$ & 18.33 & 56.67 & 81.67 \\
\hline & & $\mathrm{T}_{5^{-}} \mathrm{GA}_{3} @ 50 \mathrm{mg} / 1$ & 11.66 & 50.00 & 75.00 \\
\hline & & $\mathrm{T}_{6^{-}} \mathrm{GA}_{3} @ 100 \mathrm{mg} / \mathrm{l}$ & 10.00 & 48.33 & 73.33 \\
\hline & & $\mathrm{T}_{7}$ - NAA @ $50 \mathrm{mg} / 1$ & 16.66 & 53.33 & 78.33 \\
\hline & & $\mathrm{T}_{8^{-}}$NAA @ $100 \mathrm{mg} / 1$ & 15.00 & 51.67 & 76.67 \\
\hline & & $\mathrm{T}_{9^{-}}$Control (Water spray) & 23.33 & 61.66 & 83.33 \\
\hline & & $\mathrm{T}_{10^{-}}$Control (Absolute) & 25.00 & 63.33 & 85.00 \\
\hline & & S.Em. \pm & 1.17 & 2.69 & 2.42 \\
\hline & & C.D. $(\mathrm{P}=0.05)$ & 3.48 & 7.93 & 7.12 \\
\hline
\end{tabular}


Table.2 Influence of pre-harvest spraying treatments of chemicals and plant growth regulators on quality attributes

\begin{tabular}{|c|c|c|c|c|c|}
\hline Sr. & Parameters & Treatments & $6^{\text {th }}$ Day & $9^{\text {th }}$ Day & $12^{\text {th }}$ Day \\
\hline \multirow{13}{*}{1.} & \multirow{13}{*}{$\begin{array}{l}\text { Total Soluble Solids } \\
\left({ }^{0} \text { Brix }\right)\end{array}$} & $\mathrm{T}_{1}-\mathrm{CaCl}_{2} @ 2 \%$ & 20.62 & 22.22 & 20.37 \\
\hline & & $\mathrm{T}_{2-} \mathrm{Ca}\left(\mathrm{NO}_{3}\right)_{2} @ 2 \%$ & 19.78 & 21.48 & 19.26 \\
\hline & & $\mathrm{T}_{3}-\mathrm{CaSO}_{4} @ 2 \%$ & 18.79 & 18.21 & 17.86 \\
\hline & & $\mathrm{T}_{4^{-}} \mathrm{KCl} @ 2 \%$ & 18.29 & 18.16 & 17.66 \\
\hline & & $\mathrm{T}_{5}-\mathrm{GA}_{3} @ 50 \mathrm{mg} / \mathrm{l}$ & 18.37 & 19.15 & 17.92 \\
\hline & & $\mathrm{T}_{6^{-}}-\mathrm{GA}_{3} @ 100 \mathrm{mg} / \mathrm{l}$ & 18.61 & 19.45 & 18.06 \\
\hline & & $\mathrm{T}_{7}$ - NAA @ $90 \mathrm{mg} / \mathrm{l}$ & 18.74 & 19.58 & 18.09 \\
\hline & & $\mathrm{T}_{8}$ - NAA @ $100 \mathrm{mg} / \mathrm{l}$ & 18.76 & 19.75 & 18.13 \\
\hline & & $\mathrm{T}_{9^{-}}$Control (Water spray) & 18.24 & 18.10 & 17.63 \\
\hline & & $\mathrm{T}_{10^{-}}$Control (Absolute) & 17.90 & 17.21 & 15.94 \\
\hline & & S.Em. \pm & 0.81 & 0.73 & 0.54 \\
\hline & & C.D. $(\mathrm{P}=0.05)$ & NS & 2.16 & 1.59 \\
\hline & & C.V. \% & 7.50 & 6.56 & 5.17 \\
\hline \multirow{13}{*}{2.} & \multirow{13}{*}{ Acidity (\%) } & $\mathrm{T}_{1}-\mathrm{CaCl}_{2} @ 2 \%$ & 0.21 & 0.19 & 0.15 \\
\hline & & $\mathrm{T}_{2-} \mathrm{Ca}\left(\mathrm{NO}_{3}\right)_{2} @ 2 \%$ & 0.21 & 0.19 & 0.14 \\
\hline & & $\mathrm{T}_{3}-\mathrm{CaSO}_{4} @ 2 \%$ & 0.22 & 0.20 & 0.15 \\
\hline & & $\mathrm{T}_{4^{-}} \mathrm{KCl} @ 2 \%$ & 0.22 & 0.21 & 0.15 \\
\hline & & $\mathrm{T}_{5}-\mathrm{GA}_{3} @ 50 \mathrm{mg} / 1$ & 0.23 & 0.22 & 0.16 \\
\hline & & $\mathrm{T}_{6^{-}}-\mathrm{GA}_{3} @ 100 \mathrm{mg} / \mathrm{l}$ & 0.23 & 0.22 & 0.16 \\
\hline & & $\mathrm{T}_{7-}$ NAA @ $50 \mathrm{mg} / 1$ & 0.22 & 0.21 & 0.16 \\
\hline & & $\mathrm{T}_{8}$ - NAA @ $100 \mathrm{mg} / \mathrm{l}$ & 0.22 & 0.21 & 0.15 \\
\hline & & $\mathrm{T}_{9}$ - Control (Water spray) & 0.23 & 0.22 & 0.17 \\
\hline & & $\mathrm{T}_{10^{-}}$Control (Absolute) & 0.24 & 0.23 & 0.18 \\
\hline & & S.Em. \pm & 0.01 & 0.01 & 0.01 \\
\hline & & C.D. $(P=0.05)$ & NS & NS & NS \\
\hline & & C.V.\% & 6.80 & 7.53 & 10.27 \\
\hline \multirow{13}{*}{3.} & \multirow{13}{*}{ Total sugar $(\%)$} & $\mathrm{T}_{1}-\mathrm{CaCl}_{2} @ 2 \%$ & 20.00 & 22.61 & 18.34 \\
\hline & & $\mathrm{T}_{2--} \mathrm{Ca}\left(\mathrm{NO}_{3}\right)_{2} @ 2 \%$ & 19.30 & 21.92 & 17.36 \\
\hline & & $\mathrm{T}_{3}-\mathrm{CaSO}_{4} @ 2 \%$ & 16.32 & 15.04 & 13.08 \\
\hline & & $\mathrm{T}_{4}-\mathrm{KCl} @ 2 \%$ & 15.28 & 14.45 & 12.62 \\
\hline & & $\mathrm{T}_{5}-\mathrm{GA}_{3} @ 50 \mathrm{mg} / \mathrm{l}$ & 16.94 & 18.54 & 14.07 \\
\hline & & $\mathrm{T}_{6^{-}} \mathrm{GA}_{3} @ 100 \mathrm{mg} / \mathrm{l}$ & 17.24 & 19.22 & 15.09 \\
\hline & & T7- NAA @ 50 mg / 1 & 17.81 & 20.22 & 15.46 \\
\hline & & $\mathrm{T}_{8}$ - NAA @ $100 \mathrm{mg} / \mathrm{l}$ & 18.42 & 20.94 & 16.46 \\
\hline & & $\mathrm{T}_{9}$ - Control (Water spray) & 14.78 & 13.70 & 12.09 \\
\hline & & $\mathrm{T}_{10^{-}}$Control (Absolute) & 14.43 & 13.32 & 11.42 \\
\hline & & S.Em. \pm & 0.18 & 0.26 & 0.33 \\
\hline & & C.D. $(P=0.05)$ & 0.52 & 0.77 & 0.99 \\
\hline & & C.V. \% & 1.80 & 2.50 & 3.96 \\
\hline
\end{tabular}




\begin{tabular}{|c|c|c|c|c|c|}
\hline $\begin{array}{l}\text { Sr. } \\
\text { No. }\end{array}$ & Parameters & Treatments & $6^{\text {th }}$ Day & $9^{\text {th }}$ Day & $12^{\text {th }}$ Day \\
\hline \multirow{13}{*}{4.} & \multirow{13}{*}{ Reducing sugar (\%) } & $\mathrm{T}_{1^{-}}-\mathrm{CaCl}_{2} @ 2 \%$ & 10.31 & 11.98 & 9.98 \\
\hline & & $\mathrm{T}_{2-}-\mathrm{Ca}\left(\mathrm{NO}_{3}\right)_{2} @ 2 \%$ & 10.10 & 11.80 & 9.39 \\
\hline & & $\mathrm{T}_{3}-\mathrm{CaSO}_{4} @ 2 \%$ & 8.66 & 7.92 & 6.97 \\
\hline & & $\mathrm{T}_{4^{-}} \mathrm{KCl} @ 2 \%$ & 8.15 & 7.63 & 6.26 \\
\hline & & $\mathrm{T}_{5^{-}} \mathrm{GA}_{3} @ 50 \mathrm{mg} / \mathrm{l}$ & 8.98 & 9.62 & 7.22 \\
\hline & & $\mathrm{T}_{6^{-}}-\mathrm{GA}_{3} @ 100 \mathrm{mg} / \mathrm{l}$ & 9.12 & 9.98 & 7.98 \\
\hline & & $\mathrm{T}_{7}$ - NAA @ $@ 50 \mathrm{mg} / \mathrm{l}$ & 9.56 & 10.49 & 8.12 \\
\hline & & T8- NAA @ $100 \mathrm{mg} / 1$ & 9.79 & 10.98 & 8.78 \\
\hline & & $\mathrm{T}_{9^{-}}$Control (Water spray) & 7.97 & 7.31 & 6.11 \\
\hline & & $\mathrm{T}_{10^{-}}$Control (Absolute) & 7.80 & 7.18 & 5.72 \\
\hline & & S.Em. \pm & 0.13 & 0.14 & 0.19 \\
\hline & & C.D. $(P=0.05)$ & 0.38 & 0.42 & 0.57 \\
\hline & & C.V. \% & 2.45 & 2.58 & 4.37 \\
\hline \multirow{13}{*}{5.} & \multirow{13}{*}{$\begin{array}{l}\text { Non-reducing sugar } \\
(\%)\end{array}$} & $\mathrm{T}_{1}-\mathrm{CaCl}_{2} @ 2 \%$ & 9.71 & 10.63 & 8.36 \\
\hline & & $\mathrm{T}_{2-} \mathrm{Ca}\left(\mathrm{NO}_{3}\right)_{2} @ 2 \%$ & 9.20 & 10.12 & 7.97 \\
\hline & & $\mathrm{T}_{3}-\mathrm{CaSO}_{4} @ 2 \%$ & 7.66 & 7.12 & 6.11 \\
\hline & & $\mathrm{T}_{4}-\mathrm{KCl} @ 2 \%$ & 7.12 & 6.82 & 6.36 \\
\hline & & $\mathrm{T}_{5^{-}} \mathrm{GA}_{3} @ 50 \mathrm{mg} / 1$ & 7.96 & 8.92 & 6.85 \\
\hline & & $\mathrm{T}_{6-}-\mathrm{GA}_{3} @ 100 \mathrm{mg} / \mathrm{l}$ & 8.12 & 9.24 & 7.11 \\
\hline & & $\mathrm{T}_{7}$ - NAA @ $050 \mathrm{mg} / 1$ & 8.25 & 9.73 & 7.34 \\
\hline & & $\mathrm{T}_{8^{-}}$NAA @ $100 \mathrm{mg} / 1$ & 8.63 & 9.96 & 7.68 \\
\hline & & $\mathrm{T}_{9^{-}}$Control (Water spray) & 6.81 & 6.39 & 5.98 \\
\hline & & $\mathrm{T}_{10^{-}}$Control (Absolute) & 6.63 & 6.14 & 5.70 \\
\hline & & S.Em. \pm & 0.21 & 0.21 & 0.15 \\
\hline & & C.D. $(P=0.05)$ & 0.61 & 0.63 & 0.45 \\
\hline & & C.V.\% & 4.48 & 4.34 & 3.79 \\
\hline \multirow{13}{*}{6.} & \multirow{13}{*}{$\begin{array}{l}\text { Ascorbic acid (mg / } \\
100 \text { g pulp) }\end{array}$} & $\mathrm{T}_{1^{-}} \mathrm{CaCl}_{2} @ 2 \%$ & 21.23 & 16.16 & 13.49 \\
\hline & & $\mathrm{T}_{2-} \mathrm{Ca}\left(\mathrm{NO}_{3}\right)_{2} @ 2 \%$ & 15.41 & 9.26 & 7.71 \\
\hline & & $\mathrm{T}_{3}-\mathrm{CaSO}_{4} @ 2 \%$ & 20.27 & 15.32 & 11.29 \\
\hline & & $\mathrm{T}_{4}-\mathrm{KCl} @ 2 \%$ & 14.70 & 8.93 & 7.13 \\
\hline & & $\mathrm{T}_{5}-\mathrm{GA}_{3} @ 50 \mathrm{mg} / \mathrm{l}$ & 15.71 & 10.02 & 8.30 \\
\hline & & $\mathrm{T}_{6^{-}}-\mathrm{GA}_{3} @ 100 \mathrm{mg} / \mathrm{l}$ & 17.17 & 11.41 & 8.98 \\
\hline & & $\mathrm{T}_{7}$ - NAA @ $050 \mathrm{mg} / \mathrm{l}$ & 17.86 & 12.28 & 9.53 \\
\hline & & $\mathrm{T}_{8}$ - NAA @ $100 \mathrm{mg} / 1$ & 18.36 & 14.25 & 10.31 \\
\hline & & $\mathrm{T}_{9^{-}}$Control (Water spray) & 12.14 & 8.25 & 5.53 \\
\hline & & $\mathrm{T}_{10^{-}}$Control (Absolute) & 11.74 & 8.09 & 5.20 \\
\hline & & S.Em. \pm & 0.85 & 0.57 & 0.40 \\
\hline & & C.D. $(P=0.05)$ & 2.49 & 1.69 & 1.19 \\
\hline & & C.V.\% & 8.89 & 8.68 & 7.98 \\
\hline
\end{tabular}


On the basis of finding of the investigation it can be concluded that pre-harvest (one month) spraying of $\mathrm{CaCl}_{2} @ 2 \%$ or $\mathrm{Ca}\left(\mathrm{NO}_{3}\right)_{2}$ @ $2 \%$ is effective and found promising for maintaining quality attributes viz. TSS, total sugar, reducing sugar, non-reducing sugar, ascorbic acid with minimum physiological loss in weight and spoilage percentage.

\section{References}

Bhalerao, R. R., Parmar, B. R., Padhiar, B. V. and Bhalerao, P. P. (2010). Pre-harvest spray of different sources of calcium to improve the bio chemical qualities of sapota fruits [Manilkara achras (Mill) Fosberg] cv. Kalipatti. Asian j. of Horticulture.5 (1):93-95.

Bisen, S., Thakur, R.S. and Tembhare, D. (2014). Effect of calcium nitrate and gibberellic acid application on growth, fruit quality and post-harvest behavior of guava fruit cv. Allahabad Safeda. International Quarterly j. Enviro. Sci. 5: 55-62.

Karemera, N. J. U. and Habimana, S. (2014). Effect of pre-harvest calcium chloride on post harvest behavior of mango fruits (Mangifera indica L.) cv. Alphonso. Uni. J. Agri. Res. 2 (3): 119-125.

Kirmani, S. N., Wani, G. M., Wani, M. S., Ghani, M. Y., Abid, M., Muzamil, S., Raja, H. and Malik, A. R. (2013). Effect of pre-harvest application of calcium chloride $\left(\mathrm{CaCl}_{2}\right)$ and Gibberellic acid $\left(\mathrm{GA}_{3}\right)$ and Napthelenic acetic acid (NAA) on storage of plum (Prunus salicina L.) cv. Santa Rosa under ambient storage conditions. African J. Agric. Res.8(9): 812-818

Lal, S., Kumar, D., Singh, D., Ahmed, N., Kumar, R. and Dar, G. (2011). Effect of pre-harvest application of calcium chloride and gibberellic acid on shelf-life and post-harvest quality of apricot (Prunus Armeniaca L.) cv. Harcot. J. Horti. Sci. 6 (1): 46-51.

Rajkumar, M., Karuppaiah, P. and Andasamy, R. K. (2006). Effect of calcium on storage behavior, ripening and shelf-life of papaya cv. $\mathrm{CO}_{2}$ (Carica Papaya L.). International J. Agric. Sci. 2 (2): 480-482.

Rajput, B. S., Lekhe, R., Sharma, G. K. and Singh, I. (2008). Effect of pre and post harvest treatments on shelf life and quality of guava fruits. (Psidium guajava L.) cv. Gwalior - 27. The Asian J. Horti. 3(2): 368-371.

Ramezanian, A., Rahemi, M. and vazifehshenas, M. R. (2009). Effect of foliar application of calcium chloride and urea on quantitative and qualitative characteristics of pomegranate fruits. Scit. Hort. 121: 171-175.

Ranganna, S. (1979). Manual of analysis of fruit and vegetable products. Tata McGraw Hill Publishing Company Ltd., New Delhi.

Singh, S. K., Singh, R. S. and Awasthi, O. P. (2013). Influence of pre and post-harvest treatment on shelf-life and quality attributes of ber fruits cv. Seb. Indian J. Hort. 70(4): 610-613.

Tsomu, T. and Patel, H. C. (2014). Effect of post-harvest treatments of chemical and plant growth regulators on physical parameters of sapota fruit cv. Kalipatti. $J$. Food Process Technology. 5(3):61-64.

\section{How to cite this article:}

Desai, V.N., B.N. Satodiya and Desai, A.B. 2017. Response of Pre-Harvest Spraying Treatments of Chemicals and Plant Growth Regulators on Post-Harvest Losses and Quality Attributes of Sapota [Manilkara achras (Mill.) Forsberg] Fruits cv. Kalipatti. Int.J.Curr.Microbiol.App.Sci. 6(9): 3518-3524. doi: https://doi.org/10.20546/ijcmas.2017.609.432 